ББК 63.4

\author{
Организация конференциии и издание материалов проведень \\ при финансовой поддержке Российского фонда фундаментальных исследований, \\ проект № 19-09-20008
}

Утверждено к печати Ученым советом ИИМК РАН

Редакционная коллегия тома I: В. А. Алёкшин, Л. Б. Кирчо (отв. редакторы),

В. П. Никоноров, В. Я. Стёганцева; В. В. Терёхина

Рецензенты: д. и. н. Л. Б. Вишняцкий, д. и. н. А. А. Выборнов

Программный комитет конференции: академик РАН, д. и. н., проф. М. Б. Пиотровский

(Государственный Эрмитаж, почетный председатель); д. и. н. В. А. Лапшин (ИИМК РАН, председатель); д. и. н. А. В. Головнёв (МАЭ РАН, сопредседатель); д. и. н. В. А. Дергачёв (Высшая антропологическая школа, Молдова, сопредседатель); д. и. н. И. Ф. Попова (ИВР РАН, сопредседатель); академик АН Республики Узбекистан, д. и. н., проф. Э. В. Ртвеладзе (сопредседатель); к. и. н. А. В. Поляков (ИИМК РАН, зам. председателя); к. и. н. В. А. Алёкшин (ИИМК РАН, зам. председателя); д. и. н. Ю. Е. Берёзкин (МАЭ РАН); Dr., Prof. Н. Бороффка (Германский археологический институт, Германия); В. С. Бочкарёв (ИИМК РАН); Dr. Э. Кайзер (Свободный университет Берлина, Германия); к. и. н. М. Т. Кашуба (ИИМК РАН); д. и. н. Л. Б. Кирчо (ИИМК РАН); к. и. н. А. В. Кияшко (Южный федеральный университет); к. и. н. П. Ф. Кузнецов (СГСПУ);

к. и. н. Н. М. Малов (СНИГУ); к. и. н. В. П. Никоноров (ИИМК РАН); Ю. Ю. Пиотровский

(Государственный Эрмитаж); д. и. н., проф. Д. Г. Савинов (Институт истории СПбГУ);

к. и. н. В. Н. Седых (Институт истории СПбГУ); к. и. н. Н. Н. Скакун (ИИМК РАН);

к. и. н. Н. Ф. Соловьёва (ИИМК РАН); к. и. н. А. И. Торгоев (Государственный Эрмитаж); к. и. н. Е. А. Черлёнок (Институт истории СПбГУ)

Организационный комитет конференции: к. и. н. А. В. Поляков (ИИМК РАН, председатель);

к. и. н. В. А. Алёкшин (ИИМК РАН, зам. председателя); В. С. Бочкарёв (ИИМК РАН); ); к. и. н. М. Т. Кашуба (ИИМК РАН); д. и. н. Л. Б. Кирчо (ИИМК РАН);

А. И. Климушина (ИИМК РАН, отв. секретарь); к. и. н. В. П. Никоноров (ИИМК РАН); Ю. Ю. Пиотровский (Государственный Эрмитаж); В. Я. Стёганцева (ИИМК РАН); В. В. Терёхина

(ИИМК РАН, МАЭ РАН, отв. секретарь); к. и. н. Е. С. Ткач (ИИМК РАН); И. Ж. Тутаева (Государственный Эрмитаж); к. и. н. Е. А. Черлёнок (Институт истории СПбГУ)

Древности Восточной Европы, Центральной Азии и Южной Сибири в контексте связей и взаимодействий в евразийском культурном пространстве (новые данные и концепции): Материалы Международной конференции, 18-22 ноября 2019 г., Санкт-Петербург. Т. I. Древняя Центральная Азия в контексте евразийского культурного пространства (новые данные и концепции). К 90-летию со дня рождения патриарха евразийской археологии Вадима Михайловича Массона. - СПб.: ИИМК РАН, Невская Типография, 2019. — 291 с.

ISBN 978-5-907053-34-2

DOI 10.31600/978-5-907053-34-2 


\title{
ICONOGRAPHICAL DEVELOPMENTS AND DISTRIBUTION OF THE IRANIAN DEITIES IN CENTRAL ASIA DURING ARSACID AND SASANIAN ERAS
}

\author{
Najme Mahdi \\ Shahid Beheshti University, Tehran, Iran
}

DOI: 10.31600/978-5-907053-34-2-180-181

Keywords: Iconography, Iranian Deities, Zoroastrianism, Central Asia, Arsacid and Sasanian Periods, Kushan and Sogdian Art.

Cultic Iconography is of tremendous significance for the study of human beliefs during different historical periods. It shows even greater importance when it comes to supposed "oral societies", the cultures of which depend mostly on oral traditions, due to the missing or lack of written records. Contrary to Mesopotamian, Egyptian and Greek religions, contemporary texts referring to Iranian religions and cults are extremely scarce and fragmentary; therefore it makes artworks the most important element for cognizing religious and cultural history of pre-Islamic Iranian world. However, in the studies concerning cultic iconography in the ancient times, the Iranian world is almost absent and the iconographic repertoire of Iranian deities has not received much attention.

Despite the always-claimed opinion that the anthropomorphic figuration of deities is not a characteristic of Iranian culture, there are some principal expressions of Iranian deities manifested in precise anthropomorphic forms which cannot be disregarded. This is probably true for the skythians, various deities manifested on the Kushan coins, the gods represented on all sorts of media and locations in Sogdian art and the gods of Zoroastrian Sasanian pantheon. Thus it seems that despite the apparent aniconic trends in the religious art of the Iranian people, the anthropomorphic manifestation of deities is considerably rich especially in Eastern Iran.

The Iranian tradition of pictorial representations, in sharp contrast with ancient Egyptian and Greek ones, was usually not provided with a corresponding text explaining the pictures. Fortunately in this case, there exists the great treasury of Kushan coins, on which all the participants of the extraordinary local pantheon are labeled. The language used on these coins, from Kanishka's reign onwards, is Bactrian, a local Iranian language, which makes it possible to identify the figures represented with the Iranian gods introduced in the extant Zoroastrian texts. This magnificent set of labeled deities makes a unique key for recognizing other figures demonstrated in artworks throughout the vast Iranian world and especially the ones manifested in Sogdian paintings.

The main concern of this paper is to focus on the Iranian motifs and iconographic pantheon demonstrated and identified in the pictorial evidence accumulated from Central Asia. The unique geographic location of this vast area, along the so called "silk road" and at the fringes of rich cultural-political units with strong religious traditions, led to the emergence of a multicultural area and therefore flourishing marvelous artworks and outstanding set of religious, artistic and cultural elements of the surrounding civilizations. The material of religious imagery in Central Asia is rather excessive, the first example of which assumable obtained from BMAC (2300-1700 BC). This article therefore will exclusively consider the Arsacide and Sasanian eras and mainly the rich treasury of Kushan, Kushano-Sasanian and Sogdian art. 


\title{
РАЗВИТИЕ ИКОНОГРАФИИ И РАСПРОСТРАНЕНИЕ ИРАНСКИХ БОЖЕСТВ В ЦЕНТРАЛЬНОЙ АЗИИ В АРШАКИДСКИЙ И САСАНИДСКИЙ ПЕРИОДЫ
}

\author{
Н. Махди \\ Университет имени Шахида Бехешти, Тегеран, Иран
}

Ключевые слова: иконография, иранские божества, зороастризм, Центральная Азия, аршакидский и сасанидский периоды, кушанское и согдийское искусство.

Иконографические исследования являются одним из важнейших способов знакомства с человеческими мыслями и верованиями в разные исторические периоды. Изучение произведений искусства Центральной Азии доисламского времени из-за их обилия и разнообразия, с одной стороны, и из-за четкого отражения в них религиозных концепций, с другой, имеет очень большое значение. Эти произведения, особенно те, что происходят из двух важных регионов - Согда и Кушанского царства - являются великолепным тому подтверждением. Особое географическое расположение этих культурно-политических образований, а также важность культурных контактов вдоль трасс так называемого Шелкового пути привели к появлению и расцвету некоторых выдающихся и разнообразных художественных образов. Исследуя эти произведения искусства и имеющиеся в них иранские элементы, можно добиться точного понимания представлений древних иранцев относительно их божеств и того, как они изображались в искусстве двух вышеназванных областей. Эта цель была достигнута путем сбора серии произведений искусства из Согда и Кушанской империи, а также при помощи последовательного и систематического изучения религиозных концепций и иконографии иранских божеств на основе библиотечных и описательно-аналитических исследований. В результате было выявлено значительное число образов иранских божеств в древнем центральноазиатском искусстве, которые, что особенно интересно, в некоторых случаях соответствуют их описаниям в зороастрийских письменных источниках. Кроме того, полученные результаты и, в частности, их сравнение с памятниками искусства из западных регионов Ирана, указывают на фундаментальные различия в трактовке иконографии божеств на востоке и западе иранского мира.

\section{К ВОПРОСУ О ДАТИРОВКЕ БОЛЬШОЙ КЫЗ-КАЛЫ В МЕРВЕ}

\section{М. А. Мамедов}

Национальное управление по охране, изучению и реставрации памятников истории и культуры Министерства культуры Туркменистана, Ашхабад, Туркменистан

DOI: 10.31600/978-5-907053-34-2-181-182

Ключевые слова: Древний Мерв, Большая Кьъ-кала, датировка.

Большая Кыз-кала - один из самых известных памятников Государственного историко-культурного заповедника «Древний Мерв», внесенного в список объектов Всемирного наследия ЮНЕСКО. Изображения Большой Кыз-калы растиражированы во многих туристических изданиях, ей посвящено большое количество научных исследований и публикаций в периодической печати. В то же время Большая Кыз-кала остается едва ли не самым загадочным объектом Древнего Мерва - некогда одного из самых процветающих среди знаменитых городов на Великом Шелковом пути.

Вопрос о датировке этого уникального сооружения на юге-востоке Туркменистана оставался предметом дискуссий среди исследователей на протяжении более ста лет.

В конце XIX в. профессор Санкт-Петербургского университета, исследователь Древнего Мерва В. А. Жуковский, первым включивший в научный оборот Большую и Малую Кыз-кала, не выдвинул четкой версии о времени их возведения. Однако, обратив внимание на схожесть приема оформления гофрами стен Кыз-калы с гофрами сельджукского башен- 